\title{
A “ideia reguladora" do processo de ambientalização do setor empresarial portuário brasileiro: identificação e análise crítica
}

\author{
The "regulatory idea" of the environmentalization process in the brazilian port corporate sector: identification and critical \\ analysis
}

\author{
Jondison Cardoso Rodrigues', Edna Maria Ramos de Castro² \\ ' Doutorando em Ciências - Desenvolvimento Socioambiental, Universidade Federal do Pará, Brasil \\ ${ }^{2}$ Mestre e Doutora em Sociologia, Universidade Federal do Pará, Brasil
}

\section{Resumo}

A dimensão ambiental tem se tornado fonte de "preocupações" e de ações do setor portuário, por meio da formação de um discurso ambiental enquanto ação (ambientalização). Considerando a questão, o objetivo do artigo é identificar e analisar criticamente a "ideia reguladora" que norteia o processo de ambientalização do setor empresarial portuário brasileiro, e, consequentemente, mostrar as características ou formas de ações socioambientais que a reproduzem. O caminho metodológico escolhido foi o de caráter qualitativo, cujo delineamento da pesquisa procedeu-se em três momentos: revisão bibliográfica, pesquisa documental, e, complementarmente, como elemento corroborativo, um estudo de caso. O Port marketing and the challenge of the third generation port, da Conferência das Nações Unidas sobre Comércio e Desenvolvimento (UNCTAD) de 1992, é a ideia reguladora na qual o pressuposto é pautado em modelos conceituais dos portos, com o discurso-guia de reaproximação e integração porto-cidade, medidas de proteção ambiental e respeito ao meio ambiente e à seguridade. As características das ações reproduzidas centram-se nos trabalhadores portuários, nas capacitações pró-ativas, e, no uso da Educação Ambiental. A análise crítica mostrou que a inserção da dimensão ambiental é fonte de vantagem competitiva e saúde empresarial para, sobretudo, sustentar a lógica insaciável de acumulação de capital.

Palavras-chave: Ambientalização portuária, Brasil, Portos.

\begin{abstract}
The environmental dimension has become a source of "concern" and actions from the port sector, through the formation of an environmental discourse as action (environmentalization). In considering the issue, the aim of this article is to identify and analyze critically the "regulative idea" that guides the process of environmentalization of the Brazilian port business sector, and consequently show the characteristics and forms of environmental actions that reproduce it. The methodological approach chosen was qualitative, whose research design proceeded in three stages: literature review, document research, and in addition, as corroborative element, a case study. The Port marketing and the challenge of the third generation port, from the United Nations Conference on Trade and Development (UNCTAD) of 1992, is a regulative idea, in which the assumption is grounded in conceptual models of ports, with the speech-guide of rapprochement and port-city integration, measures for environmental protection and respect for the environment and security. The characteristics of the playback operation concentrates on port workers in proactive capabilities, and in the use of environmental education. The critical analysis showed that the inclusion of the environmental dimension is a source of competitive advantage and corporate health, especially to sustain the insatiable logic of capital accumulation.
\end{abstract}

Keywords: Port environmentalization, Brazil, Ports. 


\section{INTRODUÇÃO}

Assistimos, "recentemente", a mudanças significativas nas funções portuárias (mundial e brasileira), particularmente relacionadas à inserção da dimensão ambiental e a sua interação com os parâmetros econômicos, sociais, políticos e culturais (GONZALEZ-LAXE, 2008; 2011). Segundo Rodrigues, Castro e Figueiredo (2013a), nas últimas duas décadas os portos mundiais passaram por mudanças profundas na sua governança institucional: transferência (privatização) de parte ou de todas as operações, terceirização da mão de obra e inovações tecnológicas.

Segundo esses mesmos autores, tudo isso seria uma maneira de incluir uma variedade de novas tarefas, operações e inovações do que se considera um porto moderno, sustentável e integrado a redes de fluxos (DEBRIE; LETILLEUL; PAROLA, 2013).

A dimensão ambiental tem se tornado fonte de "preocupações" e ações do setor portuário, por meio da formação de um discurso ambiental enquanto ação, isto é, discursos que se formam a partir de suas práticas. Esse é um fenômeno que vem sendo chamado de "ambientalização empresarial portuária" (RODRIGUES, 2012). Considerando essa discussão, a pesquisa partiu da seguinte problemática de estudo: A partir de que "ideia" surge o ideário de ambientalização do setor empresarial portuário brasileiro, e quais as características ou formas de ação que a reproduzem? Portanto, esse artigo tem o objetivo de identificar e analisar criticamente a "ideia reguladora" que norteia o processo de ambientalização do setor empresarial portuário brasileiro (nas agendas, ações e políticas ambientais), e, consequentemente, de mostrar as características ou formas de ações socioambientais que a reproduzem.

\section{MÉTODO}

O caminho metodológico escolhido foi o caráter qualitativo para atingir de forma mais próxima o entendimento da complexidade de um fenômeno socioambiental (LEFF, 2000), procurando tanto encontrar o sentido desse fenômeno, quanto interpretar os significados do discurso institucional e/ou de pessoas acerca desse fenômeno (CHIZZOTTI. 2003), especialmente relacionadas à questão ambiental. Em síntese, a abordagem qualitativa, segundo Richardson (2008), pode descrever a complexidade de determinado problema, analisar a interação de certas variáveis e compreender as dinâmicas e as estratégias de um determinado grupo social em profundidade.

O delineamento da pesquisa procedeu-se em três momentos: revisão bibliográfica, pesquisa documental, e, complementarmente, como elemento corroborativo, um estudo de caso. A revisão bibliográfica foi feita com a leitura acerca da temática ambiental e as seguintes categorias implementadas no setor empresarial portuário: gestão ambiental, agenda ambiental e política ambiental portuária. Correlacionado a essa revisão, deu-se o segundo momento com a pesquisa documental. As fontes de dados da pesquisa documental foram: documentos institucionais e oficiais da Agência Nacional de Transportes Aquaviários - ANTAQ²:

a) O Programa Nacional de Capacitação Ambiental Portuária - PNCAP;

b) O livro "O Porto Verde - modelo ambiental portuário";

c) na Agendas ambientais portuárias; e,

d) na Home Page da ANTAQ.

Esses documentos foram fundamentais para expressar quem "dita às normas". No caso a ANTAQ, no entanto, cabe destacar que suas normas são replicadas, consensuadas e pactuadas da Conferência

\footnotetext{
1 Refere-se ao pensamento regulador original como estratégia. A palavra estratégia é usada, como "estratégias de universalização" (BOURDIEU, 1997), isto é, lógicas (illusio/interesse) "que fundamentam todas as normas e todas as formas oficiais (BOURDIEU, 1997).

2 É a Agência responsável por regular, supervisionar e fiscalizar as atividades de prestação de serviços de transporte aquaviário e de exploração da infraestrutura portuária e aquaviária. Segundo Rodrigues (2012) a ANTAQ é a agência responsável por organizar/mediar às regras e as normas do jogo do campo portuário, portanto é a mediadora/reguladora dos interesses (RODRIGUES, 2012), na qual os agentes sociais do campo têm "[...] os intereses asociados a estas posiciones, a reconocerse mutuamente y a reconocerse en un mismo proyecto [...]" (BOURDIEU, 1997, p.49), uma “ideia reguladora” comum (BOURDIEU, 2001).
} 
das Nações Unidas para Comércio e Desenvolvimento (UNCTAD) $)^{3,4}$, a qual possui, como ente norteador da ambientalização do setor portuário, o Port marketing and the challenge of the third generation port ${ }^{5}$. Dessa forma, é considerado também como documento oficial nesta pesquisa (RODRIGUES; CASTRO, FIGUEIREDO, 2013a), pois, segundo Rodrigues (2012), a UNCTAD trata e elabora as plataformas e normas (de jogo) das questões relacionadas ao comércio e ao desenvolvimento; além de temas conexos como finanças, tecnologia, investimentos, empreendedorismo e reestruturação logística da área marítima e portuária (UNCTAD, 1990). A UNCTAD também determina ações que contribuam para melhoria da gestão, da eficiência e para o desenvolvimento sustentável dos portos e dos serviços portuários (UNCTAD, 1993).

Para comprovar se o Port marketing and the challenge of the third generation port é ou não a "ideia" na qual se orienta o processo de ambientalização do setor empresarial portuário brasileiro, buscou-se no Programa Nacional de Capacitação Ambiental Portuária - PNCAP e no livro "O Porto Verde - modelo ambiental portuário", o discurso sobre "reaproximação e integração cidade-porto, medidas de proteção ambiental e respeito ao meio ambiente e a seguridade", que é o pensamento basilar da UNCTAD, particularmente do Port marketing and the challenge of the third generation port (UNCTAD, 1992; GONZALEZ-LAXE, 2010; SOARES, 2009).

Ainda como lente confirmativa, foi realizado um estudo de caso na Companhia Docas do Pará ${ }^{6}$ com o uso de: relatórios de gestão, informativos e folders institucionais da CDP; Programas de Educação Ambiental e os relatórios técnicos de acompanhamento dos programas de Educação Ambiental de 2007 a 2011 (dos Portos de Vila do Conde e Miramar); questionário com a Gerência Ambiental (via e-mail); e entrevistas semiestruturadas com trabalhadores que passaram por algum tipo de práticas socioambientais. Tudo isso (também) como mecanismo para visualizar quais as características ou formas de ações socioambientais que reproduzem efetivamente nos portos a "ideia reguladora".

Essa generalização só foi possível porque o estudo de caso é uma "técnica" metodológica de pesquisa que possibilita generalizar para outras instâncias (YIN, 2005). Além disso, foi compreendido, nesta pesquisa, o setor empresarial portuário, como um "Campo" (BOURDIEU, 1989), ou seja, um espaço plural de agentes em lutas e conflitos que, no entanto, possui acepções linguísticas específicas, com sistemas de regras postas que se reconhecem mutuamente em torno do mesmo projeto (político ou outro) (BOURDIEU, 1997).

O diálogo com Bourdieu é fundamental, pois, como enfatiza Assis (2000), os temas ambientais, devido sua gênese social (causa e consequência), implicam necessariamente a colaboração das diferentes áreas de conhecimento para serem problematizados, devido toda sua realidade complexa.

Por fim, a análise (análise de conteúdo dos documentos e o estudo de caso) também se pauta na sociologia ambiental crítica. Essa sociologia procura apreender criticamente a especificidade da questão ambiental e as ideias que estão por trás; o esforço analítico é de desfetichizar o ambiente e as suas ideias norteadoras, o moinho (sistema) da produção e sua expansão econômica, as relações de produção intensivas do capital e seus impactos nas relações de trabalho e na crise socioambiental (ACSELRAD, 2012). Os autores principais utilizados para dialogar foram Rodrigues (2012) e Rodrigues, Castro e Figueiredo (2013; 2013b).

\section{REVISÃO DA LITERATURA}

O arcabouço teórico baseou-se a partir das práticas, ou seja, das ações do setor empresarial portuário. Assim, nesse capítulo discorre-se sobre gestão ambiental, agenda ambiental e política ambiental portuária.

3 A UNCTAD foi instituída em 1964, pela Assembleia Geral das Nações Unidas.

4 A UNCTAD é um tinks banks, isto é, seria um lugar-comum, instâncias supostamente neutras, com pensamento também supostamente neutro, cujas posições estão totalmente demarcadas e cheio de interesses, impondo sua política (BOURDIEU; WACQUANT, 2013).

5 Esse documento teve a aprovação da United Nations (UNCTAD), Comité Maritime International (CMI), International Navigation Association, CEPAL e Banco Mundial (GOULIELMOS, 2000).

6 Empresa (Sociedade de Economia Mista) fundada em 1967, que tem responsabilidade de administrar e explorar áreas portuárias paraenses (Porto de Vila do Conde, de Belém, de Santarém, de Altamira, do Terminal Petroquímico de Miramar, de Outeiro, de Óbidos e de Itaituba) e as hidrovias da Amazônia oriental (Hidrovia Teles-Pires e Araguaia-Tocantins). Atualmente, essa empresa possui um capital social de R\$ 314.972.144,85 (CDP, 2012) 


\section{I DISCURSO AMBIENTAL ENQUANTO AÇÃO NO SETOR EMPRESARIAL PORTUÁRIO: O ACABOUÇO TEÓRICO A PARTIR DAS PRÁTICAS}

Cunha (2006) argumenta que a apropriação da perspectiva ambiental portuária estaria relacionada a um aspecto estratégico de "pactuação", na elaboração e execução de uma agenda ambiental como forma de possibilitar uma aliança com diversos "agentes sociais" que trabalham nos portos: autoridades portuárias, praticagem, operadores portuários, agências marítimas e de navegação, órgão gestor de mão de obra, autoridades portuárias e armadores (CUNHA, 2006; 2007).

Entre os setores empresariais que vêm se destacando na aplicação (nessa "pactuação") de ações, agendas e políticas ambientais, nesses últimos anos no Brasil, destaca-se o setor conhecido como "área portuária", representado pelas Companhias Docas ${ }^{7}$ (do Ceará, da Bahia, do Pará, do Espírito Santo, do Rio Grande do Norte, do Rio de Janeiro e de São Paulo). São empresas de economia mista, que têm como acionista majoritário o governo federal, com a função de explorar e organizar os portos (RODRIGUES, CASTRO; FIGUEIREDO, 2013a).

Essas Companhias foram pioneiras na implementação de práticas relacionadas à temática ambiental. Todas consideram a gestão ambiental como elemento imprescindível para o setor portuário, pois contribuiria na tomada de decisões dos gestores portuários e no desenvolvimento de política ambiental por meio de boas práticas de gestão ambiental portuária e da sustentabilidade das atividades portuárias $^{8}$ (RODRIGUES, 2012).

As ações ambientais nessas Companhias só começaram a se configurar enquanto agenda ambiental portuária, efetivamente, em 2001 com a execução do Programa Nacional de Capacitação Ambiental Portuária (PNCAP), que teve a participação de 16 portos (Santos, Vila do Conde, Itaqui, Maceió, Rio de Janeiro, Paranaguá, Rio Grande, Vitória, Salvador, Aratu, Ilhéus, Fortaleza, Pecém, Itajaí, São Francisco do Sul e Laguna) em Cursos de Meio Ambiente (ANTAQ, 2011a).

Dentro desse programa ocorreram diversos projetos, entre eles cursos sobre meio ambiente; no total de 34 cursos, sendo 6 promovidos pelo Ministério do Meio Ambiente e 28 pela Superintendência do Ensino Profissional Marítimo - SEPM (Superintendência ligada à Diretoria de Portos e Costas da Marinha do Brasil), com o objetivo de oferecer capacitação para o planejamento e a operacionalização das ações que envolvem a prevenção e o controle ambiental (RODRIGUES, 2012).

A intenção desses cursos, portanto, foi de contribuir para a formação de uma cultura de desenvolvimento sustentável (ANTAQ, 2011a; 2011b). No entanto, para Kitzmann e Asmus (2006) e Kitzmann (2009), a construção de uma Agenda Ambiental Portuária objetivou:

- Proteger a comunidade e o ambiente local dos impactos portuários negativos;

- Utilizar as melhores tecnologias disponíveis para minimizar os impactos portuários, e explorar novas soluções tecnológicas;

- $\quad$ Promover a sustentabilidade nas ações relacionadas à instalação e operação dos terminais;

- Distinguir o porto como um líder ambiental e de cumprimento da legislação;

- Engajar e educar a comunidade sobre o desenvolvimento do porto e de seus programas ambientais;

- Ampliar o conhecimento dos trabalhadores portuários no tocante à identificação dos impactos ambientais decorrentes das atividades portuárias;

- $\quad$ Envolver os trabalhadores no processo de sensibilização, na formação de valores e atitudes e na aquisição de conhecimentos;

- Incentivar a avaliação e a tomada de decisão na resolução de situações-problema e conflitos reais, e na simulação de papéis;

- Construir cenários desejados, idealizados e possíveis.

O Quadro 1 mostra os cursos de Gestão Ambiental e Educação Ambiental oferecidos e ligado ao PNCAP:

\footnotetext{
7 São autoridades portuárias que gerenciam 23 portos. Essas empresas têm a função de explorar e organizar os portos. São responsáveis por aproximadamente $35 \%$ de toda a movimentação de cargas de todo o sistema portuário brasileiro (ANTAQ, 2011a) e de $69,77 \%$ de soja, $81,19 \%$ de milho, $99,78 \%$ de açúcar e $85,5 \%$ de contêineres (ANTAQ, 2011a). Cabe enfatizar que o sistema portuário brasileiro é formado por 235 portos, sendo 42 portos públicos (ANTAQ, 2014a).

8 Wooldridge, Mcmullen e Howe (1999) enfatizam que as boas práticas ambientais no setor portuário só pode ser alcançado com a implementação efetiva de protocolos de gestão que integrem, de forma harmoniosa, as dimensões socioeconômica, normativa, os imperativos técnicos e os ambientais, dentro do que seria o porto moderno e sustentável (GONZALEZ-LAXE, 2008, 2010; BERGQVIST; EGELS-ZANDÉN, 2012).
} 
Quadro 1 - Cursos de gestão ambiental e Educação Ambiental oferecidos e ligados à PNCAP

\begin{tabular}{|c|c|c|}
\hline $\begin{array}{l}\text { Cursos Oferecidos pela Superintendência } \\
\text { do Ensino Profissional Marítimo }\end{array}$ & Ano & $\begin{array}{l}\text { Participação/Port } \\
\text { os }\end{array}$ \\
\hline O Direito à Proteção ao Meio Ambiente de Trabalho Portuário & - & Porto de Belém \\
\hline Limpeza de Reservatórios de Derivados do Petróleo & - & Porto de Belém \\
\hline EcoPorto de Belém & 2005 & Porto de Belém \\
\hline Controle de Animais Vetores & & Porto de Fortaleza \\
\hline Nos Tempos que a Pesca era uma Fartura & 2005 & Porto de Itajaí \\
\hline $\begin{array}{l}\text { A Poluição no Complexo Estaurino-Lagunar Mandaú- } \\
\text { Manguaba }\end{array}$ & & Porto de Maceió \\
\hline Plano de Gerenciamento de Resíduos Sólidos & 2004 & Porto de Natal \\
\hline $\begin{array}{l}\text { Medidas de Prevenção de Lançamento de Esgoto por } \\
\text { Embarcações no Rio Potengi }\end{array}$ & 2004 & Porto de Natal \\
\hline O Nosso Lixo, o que Fazer? & 2005 & Porto de Natal \\
\hline A Escassez e a Poluição da Água Doce & 2005 & Porto de Natal \\
\hline Saneamento Vegetal & 2005 & Porto de Recife \\
\hline Controle de Resíduos Provenientes do Trigo & & Porto de Recife \\
\hline Pequenos Vetores - Grandes Prejuízos & 2005 & $\begin{array}{l}\text { Porto do Rio de } \\
\text { Janeiro }\end{array}$ \\
\hline Como Evitar o Desperdício do Papel & 2005 & $\begin{array}{l}\text { Porto do Rio de } \\
\text { Janeiro }\end{array}$ \\
\hline Poluição na Lagoa Rodrigo de Freitas & 2005 & $\begin{array}{l}\text { Porto do Rio de } \\
\text { Janeiro }\end{array}$ \\
\hline Pombo - Da História de Cher Ami à Realidade Portuária & 2004 & Porto de Salvador \\
\hline A Pesca Predatória com Explosivo na Baía de Todos os Santos & 2004 & Porto de Salvador \\
\hline Educação Ambiental para Portuários e Aquaviários de Salvador & 2005 & Porto de Salvador \\
\hline $\begin{array}{l}\text { Responsabilidade Civil Objetiva: dos Atos Ilícitos Causados } \\
\text { ao Meio ambiente }\end{array}$ & 2009 & $\begin{array}{l}\text { Porto de São } \\
\text { Francisco do Sul }\end{array}$ \\
\hline $\begin{array}{l}\text { Projeto de Educação Ambiental para o Porto Organizado de } \\
\text { São Sebastião: "Mudando o Rumo das Coisas" }\end{array}$ & 2005 & $\begin{array}{l}\text { Porto de São } \\
\text { Sebastião }\end{array}$ \\
\hline Água de Lastro & 2004 & Porto de Santos \\
\hline Transportando para o Mundo com Consciência & - & Porto de Santos \\
\hline Contaminação Ambiental na Descarga de Granéis Sólidos & 2004 & Porto de Santos \\
\hline Impactos Ambientais nas Áreas de Estuário & & Porto de Santos \\
\hline Degradação Ambiental e Direito & 2004 & Porto de Santos \\
\hline A Degradação Ambiental no Porto de Santos & - & Porto de Santos \\
\hline Sinantrópicos na área portuária & - & Porto de Santos \\
\hline Gestão Ambiental Portuária & 2005 & Porto de Santos \\
\hline Cursos oferecidos pelo Ministério do Meio Ambiente & Período & $\begin{array}{l}\text { Participação/Port } \\
\text { os }\end{array}$ \\
\hline Gestão Ambiental Portuária (Santos/SP) & 16 a $20 / 04 / 2001$ & $\begin{array}{l}\text { Portos de Vila do } \\
\text { Conde, Itaqui, } \\
\text { Maceió, Rio de } \\
\text { Janeiro, Itaguaí, } \\
\text { Santos, Paranaguá } \\
\text { e Rio Grande }\end{array}$ \\
\hline Gerenciamento Ambiental Portuário & 10 a $14 / 12 / 2001$ & $\begin{array}{l}\text { Porto de Rio } \\
\text { Grande/RS }\end{array}$ \\
\hline Gerenciamento Ambiental Portuário & 15 a $20 / 09 / 2002$ & $\begin{array}{lr}\text { Portos } & \text { de } \\
\text { Paranaguá } & \text { e } \\
\text { Antonina } & \\
\end{array}$ \\
\hline Qualidade Ambiental e Atividade Portuária no Brasil & 7 a $10 / 02 / 2006$ & Porto de Vitória \\
\hline Qualidade Ambiental e Atividade Portuária no Brasil & 24 a $28 / 07 / 2006$ & $\begin{array}{l}\text { Portos de Salvador, } \\
\text { Aratú e Ilhéus }\end{array}$ \\
\hline Qualidade Ambiental e Atividade Portuária no Brasil & 03 a $6 / 10 / 2006$ & $\begin{array}{l}\text { Portos de } \\
\text { Fortaleza e Pecém }\end{array}$ \\
\hline
\end{tabular}

9 Nos cursos oferecidos pela Superintendência do Ensino Profissional Marítimo não foram identificadas informações sobre o período e, em alguns casos, sobre o ano dos cursos. 
Esses cursos (do PNCAP) ${ }^{10}$ pautaram-se em atividades em sala de aula (leitura de material técnico sobre legislação ambiental, gerenciamento de riscos, controle ambiental nos portos, planejamento, modelos e princípios de gestão ambiental e avaliação); atividades em grupo e aplicação de testes de acompanhamento da aprendizagem; saídas para pesquisas de campo com os "agentes portuários" (trabalhadores) (ANTAQ, 2011a; 2014b).

Os trabalhadores portuários tinham a função de identificar os impactos provocados pelo sistema portuário sobre: (1) a qualidade do ar, água, solo e sedimentos; (2) os organismos marinhos e fluviais; (3) a segurança e saúde a longo e curto prazo (de baixo, médio e/ou alto impacto); e (4) as ações e/ ou tomadas de decisões para solucionar esses problemas (ibid).

- Essas capacitações/cursos foram fundamentais, pois as tomadas de decisões para solucionar esses problemas são muito importantes no setor portuário, sobretudo porque o modus operandi portuário é insustentável, com altos riscos socioambientais de:

- Vazamento de combustíveis inflamáveis e óleo na água;

- Encalhes e derramamento da carga, como a soda cáustica;

- Transferência de organismos aquáticos nocivos e agentes patogênicos;

- Ruídos e poeira na circulação de caminhões;

- Resíduos gerados dentro dos navios e deixados nos portos de destino;

- Queda de contêiner sobre trabalhadores;

- Atropelamento na área portuária;

- Problemas ergonômicos, devido o trabalho intensivo;

- Poluição do ar por fábricas e pelo tráfego de caminhões dentro dos portos;

- Poluição produzida pelos navios através de resíduos oleosos e ruído subaquático; e,

- Erosão da área costeira dos portos devido alterações hidrodinâmicas decorrentes da circulação de navios (SAENGSUPAVANICH et al, 2009).

1. O parágrafo anterior é interessante por mostrar os impactos e riscos socioambientais provocados pelo sistema portuário, pois há concepções ingênuas, românticas, utilitaristas e tecnicistas (como um "bem de salvação") da dimensão ambiental no setor portuário, sobretudo de trabalhos acadêmico-científicos, com destaque para os trabalhos de Kitzmann (2009), Roldão (2009), Nunes (2012), Nunes, Silva e Araújo (2013), Santos (2013) e Reis (2013). Esses trabalhos apresentam pelo menos quatro concepções ingênuas:

2. Não discutem nem explicitam as contradições do atual modelo de civilização, da relação sociedade-natureza e, principalmente, das relações sociais de dominação pelo capitalismo contemporâneo, entre eles as relações de trabalho?.

3. Não colocam em pauta a natureza social, política e conflituosa da questão ambiental. Portanto, não evidenciam "as múltiplas formas sociais de apropriação e as diversas práticas culturais de sua significação", com também, as estratégias "associadas a este tipo de diagnóstico - consensualista - tendem, por certo, a esvaziar o conteúdo político do debate e, em particular, a questão da desigualdade ambiental que lhe dá substância explicativa" (ACSELRAD, 2012, p.222).

4. Retiram de cena o setor empresarial portuário como um componente da estrutura opressora de mercado (RODRIGUES; CASTRO; FIGUEIREDO, 2013b).

Não imergem sobre: quando e quem "fabrica" o ambiental (esse ambiental praticado) e a ambientalização do setor empresarial portuário, a "ideia reguladora"; tópico que será discutido adiante.

A maioria das ações socioambientais desenvolvidas nas empresas brasileiras do setor empresarial portuário teve características comuns: centraram-se na figura do trabalhador, direcionando suas ações aos trabalhadores avulsos. É o que se conclui a partir (principalmente) dos trabalhos de Kitzman e Asmus (2001), Cunha, Vieira e Rego (2007), Campo (2004), Quintana (2005), Assunção e Vieira (2005), Garcia (2005), Kitzmann e Asmus (2006) e Kitzmann (2009).

Esses autores enfatizam que o desenvolvimento de ações socioambientais é uma forma de qualificação profissional, pois permitem nivelar conhecimentos e incorporar práticas de gestão ambiental

10 A pesquisa de Rodrigues, Castro e Figueiredo, (2013b), desenvolvido no porto de Vila do Conde e Terminal de Miramar (no Estado do Pará), "mostrou" que a jornada de trabalho é desumanizante. Dependendo do trabalhador, ela pode chegar até $72 \mathrm{~h}$ semanais. 
para a resolução de conflitos. Perspectiva essa que converge com o discurso oficial da ANTAQ (ANTAQ, 2011a; 2011b; 2012b; 2014b).

Enfim, as ações socioambientais portuárias seriam um "sistema/processo de gestão ambiental portuário" com coparticipação público/privado. Corresponde a um conjunto de procedimentos para gerir ou administrar uma organização e para proteger o meio ambiente, a saúde e a segurança dos trabalhadores, dos arrendatários e da comunidade ao redor dos portos (SÁ, 2008).

\section{APRESENTAÇÃO E ANÁLISE DOS DADOS}

Como forma de responder aos objetivos propostos, em um primeiro momento apresenta-se (criticamente) a identificação, análise e discussão sobre a "ideia reguladora" que orienta o processo de ambientalização do setor empresarial portuário brasileiro, e, consequentemente, as formas de ação que se expressaram/expressa efetivamente nos portos, reproduzindo a "ideia reguladora". No segundo momento, faz-se uma análise a partir do estudo da Companhia Docas do Pará (CDP).

\section{I AMBieNTALIZAÇÃo EMPRESARIAL PORTUÁRIA BRASILEIRA E "IDEIA REGULADORA”: IDENTIFICAÇÃO E ANÁLISE}

Ainda se pensa, superficialmente (CUNHA, 2006; 2007; CUNHA; VIEIRA; REGO, 2007; LOURENÇO, 2012), que o processo de ambientalização portuária brasileira está ligado ao Plano Nacional de Gerenciamento Costeiro Brasileiro (constituído pela Lei 7.661, de 16/05/88), cuja finalidade, de maneira geral, é a busca do estabelecimento de normas gerais que visem à gestão ambiental da zona costeira do país. Esse plano é base, segundo os autores supracitados, nas políticas setoriais (para a formulação de políticas, planos e programas estaduais e municipais) voltadas à gestão integrada dos ambientes costeiros, marinhos e, consequentemente, portuários.

Também é costumeiro dizer que essa ambientalização adveio de convenções marítimas internacionais (os autores que pensam assim são: CUNHA, 2006; 2007; CUNHA; VIEIRA; REGO, 2007; KITZMANN; ASMUS, 2006), entre elas: a) International Convention on Load Lines, 1966; b) International Convention on Tonnage Measurement of Ships, 1969; c) Convention on the International Regulations for Preventing Collisions at Sea, 1972; d) International Convention for the Prevention of Pollution from Ships, 1973; e) International Convention for the Safety of Life at Sea, 1974; f) Merchant Shipping (Minimum Standards) Convention, 1976; g) International Convention on Standards for Training, Certification and Watchkeeping for Seafarers, 1978 (SAENGSUPAVANICH et al, 2009).

A "ideia reguladora" de ambientalização empresarial portuária no Brasil também não se deu com a constituição da Agenda Ambiental Portuária, em $1998^{10}$ (os autores que se fincam nessa perspectiva: KITZMANN; ASMUS, 2006; KITZMANN, 2009; LIMA, 2009; KOEHLER; ASMUS, 2010; CASTRO; ALMEIDA, 2012; LOURENÇO, 2012). Essa agenda é posterior a "ideia reguladora", que será tratada logo em seguida.

- A "ideia reguladora" de ambientalização empresarial portuária no Brasil está disposta em escala hierárquica de influência: Libro verde sobre los puertos y las infraestructuras marítimas, elaborada pela Comunidade Econômica Europeia (em 1995); Port Reform Toolkit, pelo Banco Mundial (primeira edição em 2001); Environmental Considerations for Port and Harbour Developments, do Banco Mundial (em 1990); Port marketing and the challenge of the third generation port, da Conferência das Nações Unidas sobre Comércio e Desenvolvimento (UNCTAD) (em 1992). Os três primeiros documentos tinham os seguintes objetivos:

- The Port Reform Toolkit: nortear a "renovação/reegenharia institucional", a implementação de reformas/flexibilidade trabalhistas, ambientais e a inserção de tecnologias de comunicação e informação.

- Libro verde sobre los puertos y las infraestructuras marítimas: incentivar e integrar melhor os aspetos ambientais no planejamento do desenvolvimento portuário e gestão integrada

11 Sobre ela, a ANTAQ (2011a) descreve: [Ela é] considerada um marco do subsetor portuário, foi concebida em 1998 [pela resolução do CIRM (Comissão Interministerial para os Recursos do Mar)] pelo Grupo Integração do Gerenciamento Costeiro. Essa Agenda tem como foco a inter-relação dos ambientes costeiro e marinho. $\mathrm{O}$ objetivo é de promover o controle ambiental da atividade portuária e o gerenciamento costeiro e ambiental nos portos organizados; regulamentar os procedimentos da operação portuária, adequando-os aos padrões ambientais; e, por fim, capacitar recursos humanos para a gestão ambiental portuária (ANTAQ, 2011b). 
das regiões costeiras, que inclui a evolução estratégica do impacto ambiental e a recepção de resíduos nos portos da União Européia. Por "coincidência" a ANTAQ (Agência Nacional de Transporte Aquaviários) possui uma publicação chamada Porto Verde: O Modelo Ambiental Portuário (ANTAQ, 2011).

- Environmental Considerations for Port and Harbour Developments: fornecer informações adicionais e orientações sobre como proceder com todos os problemas ambientais, além de recomendar a implementação de projetos de monitoramento e auditoria ambiental nos portos.

Todos os três tiveram grande influência (as referências dos documentos supracitados estão disponíveis, respectivamente, em: Comision Europea (1997), Banco Mundial (2007), Davis et al. (1990), UNCTAD (1992)). Entretanto, o que teve maior influência, pois trouxe uma sistematização dos três anteriores no processo de modernização portuária, foi o ("idéia reguladora") Port marketing and the challenge of the third generation port, da UNCTAD: criado em 1992 e pautado em modelos conceituais de portos, que estabeleceu os seguintes critérios-chave: políticas de desenvolvimento portuário em relação às estratégias e atividades; alcance e extensão das atividades portuárias; e integração das atividades e organização do porto (UNCTAD, 1992, p.13).

Esse modelo estabeleceu uma sequência de três gerações (linear evolutivo) de portos (Quadro 2).

Essa "ideia reguladora" aparece no setor empresarial portuário e é resultado do próprio processo de reestruturação produtiva ${ }^{12}$ no setor portuário na década de 1990 (com a criação do modelo de portos

Quadro 2 - Três gerações/modelos de portos pautados na UNCTAD

\begin{tabular}{|c|c|c|}
\hline $\begin{array}{l}\text { Portos de primeira } \\
\text { geração }\end{array}$ & $\begin{array}{l}\text { Portos de segunda } \\
\text { generação }\end{array}$ & Portos de segunda generação \\
\hline 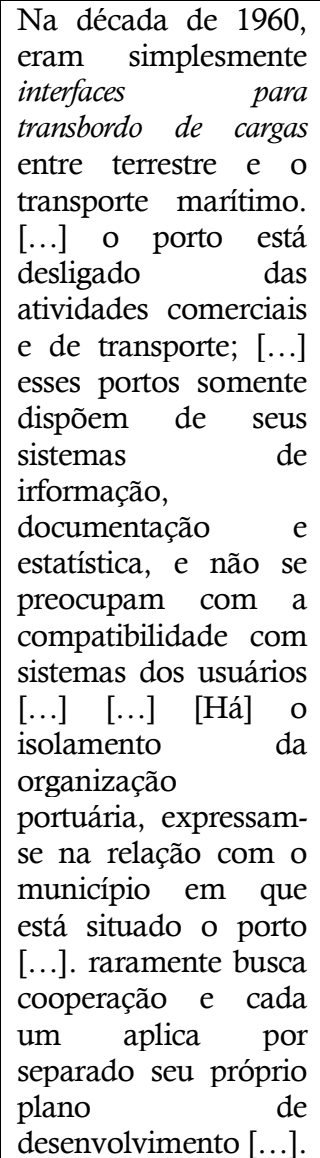 & $\begin{array}{l}\text { [Aparece no fim da } \\
\text { década de } 1970 \text { e início } \\
\text { da década de 1980] } \\
{[\ldots] \text { o porto se }} \\
\text { considera como um } \\
\text { centro de serviços de } \\
\text { transporte e de serviços } \\
\text { industriais. Assim os } \\
\text { portos podem oferecer } \\
\text { aos seus usuários } \\
\text { serviços industriais ou } \\
\text { comerciais que não } \\
\text { guardam relação direta } \\
\text { com a atividade } \\
\text { tradicional de carga e } \\
\text { descarga. [...] no porto } \\
\text { de segunda geração, a } \\
\text { organização é a mesma } \\
\text { que o porto de primeira } \\
\text { geração. [...] mantém } \\
\text { uma relação mais } \\
\text { estreita com as as } \\
\text { empresas de transporte } \\
\text { e de comércio que tem } \\
\text { construído açãos/elaboração } \\
\text { instalaçõa suas } \\
\text { do zona do porto. [...] } \\
\text { também tem uma } \\
\text { relação ainda estreita } \\
\text { com município [...]. }\end{array}$ & $\begin{array}{l}\text { Estes portos aparecem durante a década de } 1980 \text { devido } \\
\text { principalmente a difusão mundial da conteinerização em } \\
\text { grande escala e a intermodalidade [...] É responsável } \\
\text { pela adoção de política, o administrador e os } \\
\text { administradores do porto de terceira geração têm } \\
\text { compreensão e atitude muito diferente no que se refere a } \\
\text { exploração e o desenvolvimento de seus portos. O porto } \\
\text { é um nó dinâmico da rede complexa de produção e } \\
\text { distribuição internacional. [...] As atividades e serviços } \\
\text { dos seus serviços são especializados, variáveis, e } \\
\text { integradas. [...] possuem logística e IED (Intercâmbio } \\
\text { Eletrônico de dados), [...] Conexões com a agua, ar e } \\
\text { terra, [...] prestam serviços complementares [cooperam], } \\
\text { [...] [incentivam] regulamentações aduaneiras } \\
\text { simplificada. [...] É difícil que um porto chegue a ser de } \\
\text { terceira geração sem realizar algumas mudanças } \\
\text { orgânicas que afetam a relação entre as distintas que se } \\
\text { realizam na zona portuária e a relação entre porto e o } \\
\text { municipio [porto-cidade] (e o governo local e central). } \\
{[. .] \text { Os portos modernos têm que estar equipados das }} \\
\text { instalações necessárias para a proteção do meio } \\
\text { ambiente. Faz tempo que os navios e as cargas são } \\
\text { fontes de contaminação na zona portuária (por exemplo, } \\
\text { por residuos dos navios e as cargas perigosas), e com as } \\
\text { atividades industriais na zona do porto os problemas } \\
\text { ambientais estão chegando a ser uma das principais } \\
\text { preocupações dos administradores dos portos. Nos } \\
\text { Estados Unidos têm vários planos de desenvolvimento } \\
\text { importantes portos que não podem operar até não } \\
\text { receberem a aprovação das autoridades após considerar } \\
\text { as repercusões [acidentes] ambientais. }\end{array}$ \\
\hline
\end{tabular}

Fonte: (UNCTAD, 1992, p.13-22) [Tradução e grifo nosso].

12 Segundo Alves (2007; 2008), reestruturação produtiva é um movimento de posição (e reposição) de métodos de produção de mais-valia relativa, que se difundiram no século XX (sobretudo na década de 1980) nos países centrais, cujos elementos compositivos são as inovações organizacionais, as tecnológicas e as sócio-metabólicas. 
de terceira geração) (JHUEL, 2001; FREITAS, 2011), com a reaproximação e integração porto-cidade, medidas de proteção ambiental e respeito ao meio ambiente e à seguridade, que é o pensamento basilar da UNCTAD (UNCTAD, 1992; 1993; 1996; GONZALEZ-LAXE, 2010; SOARES, 2009). Isso pode ser visualizado nos fragmentos abaixo, no Programa Nacional de Capacitação Ambiental Portuária (PNCAP), na Agendas ambientais portuárias, no livro "O Porto Verde - modelo ambiental portuário" e na Home Page da ANTAQ, respectivamente:

O PNCAP tem papel fundamental no desenvolvimento de ações de capacitação que permitam nivelar conhecimentos e integrar todos os segmentos atuantes na área do porto organizado, incorporando, na prática da gestão ambiental, a resolução de conflitos, produzindo, assim, resultados com ganhos nas dimensões políticas, sociais, econômicas, tecnológicas e culturais (ANTAQ, 2014b, sp) [grifo nosso].

Relação porto-cidade:

- Informações sobre o Plano Diretor do Município e do Plano de Desenvolvimento e Zoneamento do Porto;

- Informações sobre as vias de acesso às instalações portuárias e atividades desenvolvidas no entorno;

- Atividades desenvolvidas pelo porto com a comunidade e demandas da comunidade local;

- Características da população, direta e indiretamente relacionadas com a atividade portuária;

- Vinculação do porto à cidade na forma de emprego, comércio, cultura;

- Influências positivas e negativas da atividade portuária sobre a cidade e a comunidade;

- Diagnóstico dos conflitos existentes na área de influência do porto e situações a serem harmonizadas;

- Informações acerca do Zoneamento Ecológico Econômico, Planos Diretores Municipais, Projeto Orla. (ANTAQ, 2011b, p.35) [grifo nosso]

[...] Gestão ambiental deve ser uma ferramenta eficiente e efetiva de redução dos impactos ambientais, tornando a Administração Portuária responsável nesse campo. Nesse sentido, ela deve ter consciência ambiental e uma conduta adequada à importância dessas questões. Outro componente fundamental para a gestão é a capacitação ambiental. Inclui, necessariamente, a mobilização de todas as forças e disposição para a gestão, sustentada por uma base de dados técnicos e científicos atuais, obtidos pelo próprio gestor portuário ou por terceiros por ele contratados com essa finalidade, pela implantação de instrumentos de aferição ambiental, por agendas estabelecendo metas e prazos, entre outros instrumentos (ANTAQ, 2011a, p.65) [grifo nosso].

A gestão ambiental é um processo contínuo e adaptativo, que se inicia no seio da própria organização, no momento em que ela define (e redefine) seus objetivos e metas, bem como implementa ações relativas à qualidade de seus produtos, do ponto de vista ambiental (sustentabilidade). Esse processo inclui a satisfação dos clientes e da comunidade envolvida nesse processo, que tem como finalidade primordial a proteção dos recursos naturais e a garantia de saúde e segurança ocupacional de seus empregados (ANAQ, 2014c, sp) [grifo nosso].

Esse processo de "ambientalização" do discurso empresarial portuário é expresso, hoje, no modelo de gestão ambiental portuária conduzido pela ANTAQ. A Figura 1, abaixo, apresenta as fases de concepção, implantação e operação dos empreendimentos portuários, visando o controle da degradação ambiental por meio da incorporação de princípios e conceitos de sustentabilidade, diagnóstico, capacitação, avaliação, monitoramento e da compreensão da necessidade de evitar os impactos e os elevados custos de recuperação dos recursos naturais degradados (vide Figura 1).

No setor empresarial portuário brasileiro, segundo Rodrigues (2012), a maioria das ações socioambientais desenvolvidas apresenta uma característica comum (pontuada na Figura 1 acima): centram-se na figura do trabalhador, particularmente os trabalhadores avulsos, pois, como afirma Vasconcelos (2011), o estabelecimento de um modelo socioambiental (mudança cultural) no ambiente 
portuário deve ser realizado por meio do trabalhador, no seu trabalho, por capacitação, como forma de favorecer a logística da empresa.

O trabalhador é projetado na concepção da empresa para ser capaz de empreender e entender a problemática ambiental em toda a sua complexidade, tanto na gestão do uso dos recursos ambientais quanto na identificação e tomadas de decisões para melhoria da qualidade do trabalho portuário e do meio ambiente (RODRIGUES, 2012). Isto é corroborado no PNCAP (espesso na secção 3 desse artigo).

Assim, a inserção do discurso ambiental ou ambientalização portuária implica apresentar o desenvolvimento sustentável como oportunidade, fonte de vantagem competitiva e saúde empresarial, já que no atual cenário de alta competitividade portuária (FILLOL et al, 2012) um outro elemento de

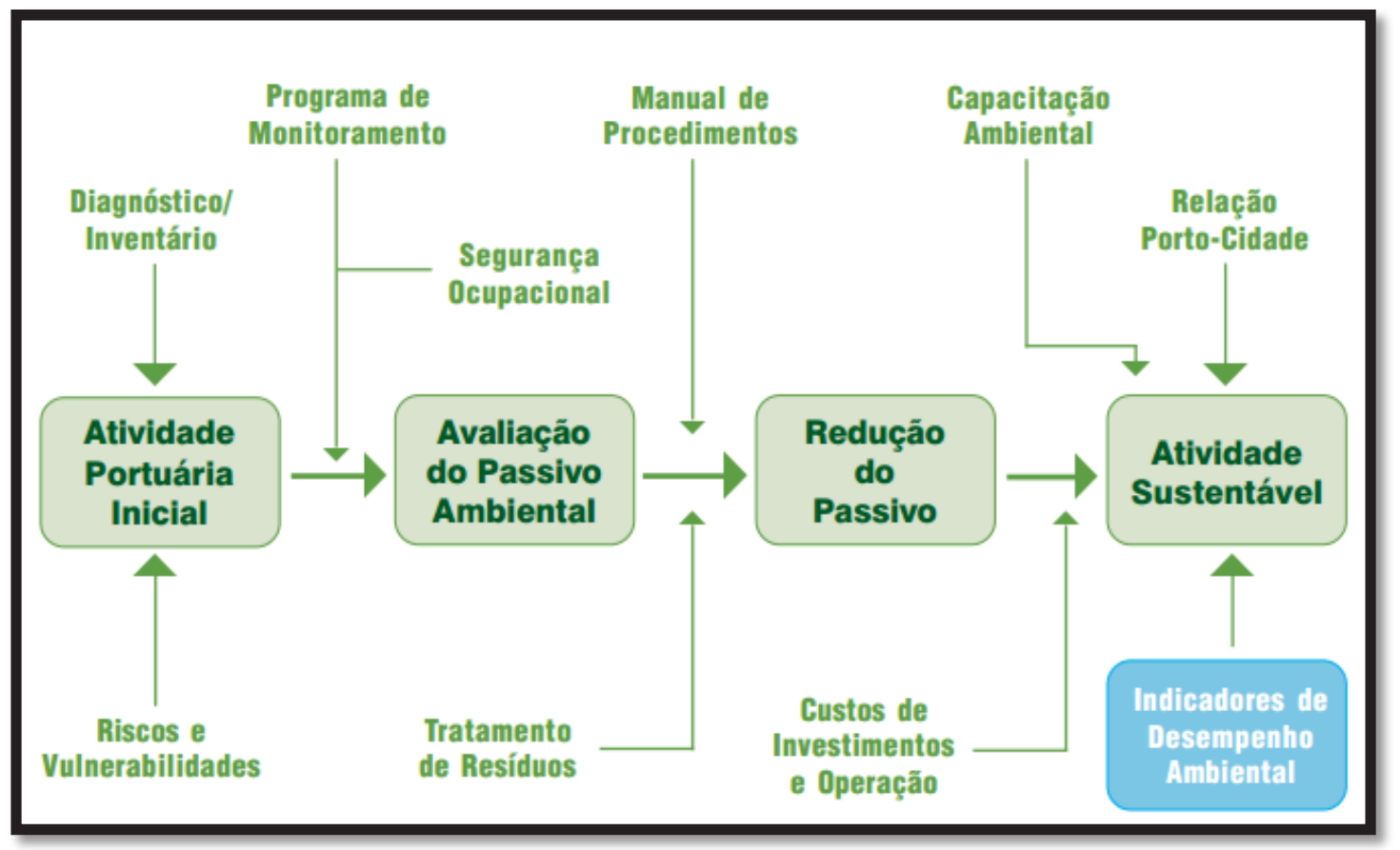

Figura 01 - Modelo de Gestão Ambiental Portuário

Fonte: ANTAQ (2011b, p.65)

ação seria forma de se destacar e diferenciar nesse setor, e ganhar respeito e parceiros.

No entanto, essa perspectiva apresenta-se muito diferente dos trabalhos de Garcia (2005), Kitzmann (2009), Roldão (2009), Nunes (2012), Reis (2013) e Nunes, Silva e Araújo (2013) quando são expostos acriticamente, de forma generalizante-reducionista, ou/e legitimadora do modus operandi portuário:

- Acrítica: à medida que não fazem a "crítica da racionalidade econômica e de sua referência exclusiva à lógica do mercado, da mesma forma crítica às instituições econômicas e seus efeitos em termos de conscientização ideológica e política" (TEISSERENC, 2011,p.159). As causas da chamada "crise ambiental" fica reduzida ao desperdício (por falta de boa gestão) de matéria e energia (ZACARIAS, 2009).

- - Generalizante-reducionista: ao mostrar a gestão ambiental como instigadora e constituidora de uma postura proativa, e deixando de enfatizar que envolvimento (ambientalização, por meio de gestão ambiental, por exemplo) é "compreendido" no setor empresarial como mecanismo ou estabelecimento de diretrizes proativas de gestão que intensifiquem a captura da subjetividade para o trabalho, para que se trabalhe mais e se gerencie os negócios da empresa. Um disciplinamento do trabalhador à lógica (exploradora) do capital econômico-financeiro globalizado.

- - Legitimadora do modus operandi portuário: ao querer a constituição de uma postura proativa, de gestão ambiental crítica, questionadora dos projetos civilizatórios; discurso, no entanto, contraditório e legitimador, pois a crise ambiental não passa da manifestação 
da lógica "produtiva destrutiva" do processo de produção e acumulação do capital. Como enfatiza Lowy (2013):

Não se trata da "má vontade" de tal ou qual multinacional, ou governo, mas da lógica intrinsecamente perversa do sistema capitalista, baseado na concorrência impiedosa, nas exigências de rentabilidade, na corrida atrás do lucro rápido; uma lógica que é, necessariamente, destruidora do meio ambiente e responsável pela catastrófica mudança do clima (LOWY, 2013, p.81). [O capitalismo] em sua dinâmica e no seu funcionamento e, portanto, são destruidoras da saúde do trabalhador, bem como do meio ambiente. A própria estrutura do processo produtivo, da tecnologia e da reflexão científica a serviço dessa tecnologia e desse aparelho produtivo é inteiramente impregnada pela lógica do capitalismo e leva, inevitavelmente, à destruição dos equilíbrios ecológicos do planeta (Idem, p.82).

Apesar dessa incompatibilidade, como explicitado na citação acima de Lowy, os trabalhos de Garcia (2005), Silva (2006), Kitzmann e Asmus (2006), Cunha (2006; 2007), Reis (2013) e Santos (2013) fazem defesas a ambientalização do setor empresarial portuário, com a ilusão de ressignificar o capitalismo (corrigindo "suas falhas técnicas") ou com falácia de humanização capitalista. Suas perspectivas estão "banhadas" de apologias, como "bem de salvação", uma panaceia.

\subsection{UMA ANÁLISE A PARTIR DO ESTUDO DA COMPANHIA DOCAS DO PARÁ (CDP)}

Vantagem competitiva e saúde empresarial no setor empresarial portuário são expressas na pesquisa desenvolvida por Rodrigues, Castro e Figueiredo (2013b), no qual discorre sobre as práticas de Educação Ambiental (EA) e gestão ambiental empreendidas nos portos da CDP:

As ações de EA na área empresarial portuária intensificam-se por meio de sistemas de gestão e de responsabilidade, mas se deslocando de estratégia de obtenção de licenças ambientais para estratégias de: (1) promover acumulação de "capital simbólico", para publicização de uma boa imagem da empresa; (2) promover diminuição de investimentos em tecnologias e planejamentos; e (3) conseguir a legitimação do modus operandi portuário, que produz nos trabalhadores a qualificação maciça contínua, o 'ajustamento' para o trabalho, para o gerenciamento ambiental dos negócios da empresa [...] (RODRIGUES; CASTRO; FIGUEIREDO, 2013b, p.275).

Essa apropriação ambiental, no setor empresarial portuário mundial e no Brasil, ocorreu, como bem menciona Goulielmos (2000), porque não havia uma política ambiental portuária, o que dificultava a entrada no modelo de "Portos de Terceira Geração" (PTG). Nesse momento (década de 1990), consideravam-se as atividades portuárias como parte do transporte e, principalmente, parte da rede multimodal e do sistema global de fluxos econômicos. A partir desse ponto de vista, deveria ter os objetivos ou programas fincados em uma "modalidade sustentável" (GOULIELMOS, 2000). Um exemplo da inserção ao modelo de portos de terceira geração, modalidade sustentável, expressou-se nos portos da CDP (Estado do Pará, Amazônia Oriental).

A inserção nessa lógica (ou pelo menos a tentativa) do modelo PTG nos portos paraenses deu-se a partir do ano 2000: com o lançamento do (1) Programa de Revitalização de Áreas Portuárias (REVAP); concatenado a vários (2) processos de reestruturação produtiva.

O processo de reestruturação produtiva se dá de forma exata na CDP em 1997, quando houve a redução dos níveis hierárquicos de 4 para $3^{13}$; com o enxugamento do número de trabalhadores (estabilidade cuja média foi de 297,8 trabalhadores); e, com a diminuição drástica das funções de chefia e comissionadas, passando de 83 cargos de confiança para 46 funções gratificadas (CDP, 2001, p.31). Além de políticas de qualificação, inserção tecnológica, multifuncionalidade, planos de demissão voluntária, participação em lucros e resultados, política para formação de sindicalismo dócil ou da empresa (RODRIGUES, 2012).

A partir de 2000, a reestruturação se deu de forma mais vigorosa na CDP com o Programa

13 Para Castro (1995), seria a base para um melhor funcionamento, organização e disciplina no trabalho e na empresa. Segundo Castro (1995) a reengenharia do organograma significaria a redução das distâncias entre direção e operadores (possibilitando uma estruturação horizontalizada) e, consequentemente, melhor otimização da eficiência produtiva da CDP. 
de Revitalização de Áreas Portuárias (REVAP). Nesse momento é inaugurado um espaço de turismo, cultura e lazer em Belém, a "Estação das Docas" (Complexo: Boulervard das artes, galeria da Estação, Boulervard da Gastronomia, Restaurante, sala de teatro) e o Projeto Ver o Rio - primeiros projetos de REVAP efetivados no Brasil (CDP, 2001).

Esses espaços foram fundamentais, pois uma característica marcante dos Portos de Terceira Geração é a boa relação porto-cidade, como forma de demonstrar que as riquezas que "circulam" pelos portos são extraídas e repassadas à sociedade, remontando ao período (ideário) da belle-époque (RODRIGUES, 2012).

Esse processo de "Revitalização", de modernização portuária, resultou, em 2003, na política ambiental portuária da CDP, e expressa da seguinte forma na missão da empresa:

Promover o desenvolvimento socioeconômico da região de sua influência e, em particular, do Estado do Pará, através do exercício da função de Autoridade Portuária, promovendo a integração entre os diversos modais de transporte através da oferta de instalações e serviços portuários e de hidrovias, buscando a satisfação de seus clientes diretos e indiretos e aplicando na questão ambiental os princípios de segurança e controle de perdas e respeito à Legislação Ambiental, por considerar o meio ambiente uma questão prioritária (CDP, 2004, p.8) [grifo nosso].

A boa relação porto-cidade seria fundamental (ANTAQ, 2011b), pois, como já dito e enfatizado por Rodrigues (2012), seria uma forma de mostrar que esse e nesse modal circulam riquezas que são/seriam distribuídas equitativamente a sociedade, como bem enfatiza CDP (2010a), e a fala da Gerência Ambiental (GERAMB) da CDP (realizado por meio da aplicação de questionário, via e-mail, 25/11/2011), respectivamente:

[A] política institucional, ao mesmo tempo em que sinaliza grandes desafios para o futuro, resgata a credibilidade e efetiva o seu papel como empresa estatal que viabiliza o desenvolvimento econômico da região e do país com responsabilidade social e ambiental (CDP, 2010a, p.12) [grifo nosso].

Inicialmente [da política de responsabilidade socioambiental da CDP] era a obtenção das Licenças de Operação e atualmente é tornar a CDP uma empresa com comportamento ético, contribuindo para o desenvolvimento econômico, melhorando a qualidade de vida de seus empregados, da comunidade local e da sociedade como um todo [grifo nosso].

O discurso da CDP acima é, no entanto, contraditório, pois o que se evidencia no entorno dos portos da CDP (em pesquisa de campo efetuado) é a desigualdade, a "miséria" e as contradições sociais. Realidades evidenciadas em outros portos (RODRIGUES; LEMOS, 2012) (tornando-se algo comum) como Aratu, na Bahia, cujos interesses de boa relação porto-cidade restringem-se "a instâncias da reprodução econômica, em prol dos grandes grupos que se apropriam desse importante espaço" (RIOS, 2009, p.349). O interessante é que os trabalhos de Reis (2013), Nunes (2012), Costa (2013), Nunes, Silva e Araújo (2013) não fazem qualquer alusão a esse debate; isso ocorre porque foram/são participantes-membros da elaboração e execução de programas de Educação Ambiental nos portos da CDP até hoje.

Em síntese, a relação porto-cidade seria uma estratégia para que a dimensão ambiental não se torne obstáculo ambiental e não-ambiental ao (neo) desenvolvimento(ismo) (MUNHOZ, 2009; KAISER;, BEZERRA; CASTRO, 2013); como também para que legitime (e justifique) os investimentos em políticas públicas em logística portuária, sendo assim possível conciliar sustentabilidade econômica e sustentabilidade ambiental de maneira a "favorecer crescimento econômico sustentado e com melhores possibilidades de engendrar uma sociedade mais justa e próspera" (BRASIL, 2008, p.48). Esse discurso conciliatório concebe que o desenvolvimento econômico é sinônimo de desenvolvimento social e ambiental. O equívoco (vulgar, intencional e tendencioso) talvez ocorra, no caso do setor portuário, pois os portos são ainda concebidos como "um instrumento a serviço de um projeto de desenvolvimento" (MONIÉ; VIDAL, 2006, p.977). Discurso esse reproduzido, por exemplo, no trabalho de Garcia (2012, p.394): 
Fica claro que o desenvolvimento econômico é necessário para que ocorra proteção ambiental e, considerando que a pobreza é uma das causas mais degradantes desse meio, o aumento da riqueza faz gerar essa proteção. Destaca-se, portanto, como contribuição gerada pela instalação dos portos em uma cidade, esse "aquecimento" na economia que ele traz em vários setores da sociedade, proporcionando melhoria de vida. Essa melhoria gerada pelo aumento do potencial econômico da população liga-se diretamente à proteção dos direitos sociais dessas pessoas, garantindo-lhes o mínimo existencial, que seria o mínimo necessário para a manutenção dos direitos fundamentais sociais.

\subsection{Características ou formas de aÇões socioambientais que reproduzem a "IDeIA Reguladora”: uma análise a PARTIR DA CDP}

A CDP vem promovendo, nos seus portos, ações que "refuerzan las medidas de protección medioambiental y de seguridad" (GONZÁLEZ-LAXE, 2011, p.37-8), isto é, ancoradas na "ideia reguladora" da UNCTAD, como demonstrado no Quadro 3:

Pode-se observar tanto nas ações do PNCAP (já realizadas, apresentadas na secção 3 desse artigo) quanto nas ações CDP (quadro acima), que as formas de ações estão centradas em práticas de Educação Ambiental. Isso porque, segundo a coordenadora dos Programas de Educação Ambiental dos Portos de Miramar, Belém e Vila do Conde, Silva (2008, p.2):

Educação Ambiental, então, compreendida como processo crítico de mudança de posturas, atitudes e valores dos sujeitos humanos em suas relações com a natureza, promovendo a participação de todos, pode contribuir para a redução dos problemas ambientais presentes nos portos e em seu entorno (SILVA, 2008, p.2). [No programa de Educação Ambiental do Porto de Belém, insurge o mesmo objetivo específico: "A Educação Ambiental pode contribuir para redução dos problemas ambientais presentes no terminal e em seu entorno" (CDP, 2010b)]

O fragmento acima aponta três compreensões da ambientalização portuária que são as características das ações socioambientais, reprodutoras da "ideia reguladora". A primeira é que os principais personagens ("soldados") são os trabalhadores portuários, como pode ser observado e expresso no questionário (via e-mail, 25/11/2011) realizado com a Gerência Ambiental (GERAMB) da CDP:

Os mais beneficiados com as ações ambientais são os atores envolvidos nas unidades portuárias como os empregados, terceirizados, funcionários do OGMO, usuários, taxistas, carregadores, vendedores de lanche e a comunidade do entorno. [A pergunta feita foi: Quais foram os públicos beneficiados pelas ações até hoje? Você pode enumerar (e os seus respectivos cargos que ocupam)?].

A segunda característica é a implementação de capacitações (cursos) para o desenvolvimento de conhecimentos, habilidades e atitudes pró-ativas, visando à intervenção individual e coletiva na unidade portuária, tanto na gestão do uso dos recursos ambientais, quanto na identificação e tomadas de decisões para melhoria da qualidade do meio ambiente portuário. Além disso, visa-se promover a diminuição de investimentos: em tecnologias, ações e planejamentos ambientais para mitigar, minimizar e/ou compensar impactos ambientais sistêmicos do processo produtivo do setor empresarial portuário. Os trabalhos de Rodrigues, Castro e Figueiredo (2013a; 2013b) e Rodrigues (2012) corroboram com a afirmação anterior.

A terceira característica é o uso da Educação Ambiental, como uma iniciativa de qualificação, com a finalidade de estimular o engajamento participativo, principalmente para o gerenciamento de riscos, resíduos sólidos e efluentes líquidos (uma gestão ambiental dos negócios da empresa). Até 2011 "a CDP investe 20\% dos custos na área ambiental em Projetos de Educação Ambiental" (expressos no questionário junto a GERAMB/CDP).

O engajamento dos trabalhadores pode ser percebido, abaixo, nas entrevistas com trabalhadores portuários da CDP:

[...] Como posso dizer, porque tivéssemos mais cuidado, cuidado não só mesmo com a gente, com o companheiro, mais com o próprio produto, derrame do produto, passamos trabalhar 
Quadro 3: Projetos de Educação Ambiental e Responsabilidade Socioambiental realizado e em processo

\begin{tabular}{|c|c|c|c|c|}
\hline \multirow[t]{2}{*}{ Projeto } & \multirow[t]{2}{*}{ Objetivo } & \multirow[t]{2}{*}{ Público alvo } & \multicolumn{2}{|c|}{ Prazo } \\
\hline & & & Inicio & Término \\
\hline $\begin{array}{lr}\text { Projeto CDP } & \text { na } \\
\text { escola - Educação } \\
\text { Ambiental } & \text { e } \\
\text { Exercício } & \text { de } \\
\text { Cidadania } & \text { no } \\
\text { Ensino } & \\
\text { Fundamental } & \text { no } \\
\text { município } & \text { de } \\
\text { Santarém. } & \\
\end{array}$ & $\begin{array}{l}\text { Desenvolver ações que propiciem o } \\
\text { desenvolvimento de uma postura crítica diante } \\
\text { da conservação e preservação do meio } \\
\text { ambiente. (Valor: } \mathrm{R} \$ 119.991,12)\end{array}$ & $\begin{array}{l}\text { Alunos da Escola } \\
\text { Municipal de } \\
\text { Ensino } \\
\text { Fundamental } \\
\text { Sofia Imbiriba. }\end{array}$ & $\begin{array}{l}20 / 11 / \\
2012\end{array}$ & $\begin{array}{l}19 / 11 / 20 \\
13\end{array}$ \\
\hline $\begin{array}{l}\text { Projeto de } \\
\text { Educação } \\
\text { Ambiental do } \\
\text { Porto de Belém }\end{array}$ & $\begin{array}{l}\text { Desenvolver ações formativas de Educação } \\
\text { Ambiental no interior do Porto de Belém e seu } \\
\text { entorno de modo a envolver todos os } \\
\text { funcionários na construção de novas } \\
\text { intervenções no meio ambiente, considerando } \\
\text { as necessidades de conservação ambiental e } \\
\text { fortalecendo assim a Política de Meio } \\
\text { Ambiente da empresa e seus instrumentos. } \\
\text { Desenvolver processos de pesquisa acerca dos } \\
\text { resultados dessa Política de Gestão Ambiental } \\
\text { nos últimos 05 anos para verificar sua } \\
\text { adequação aos interesses da sustentabilidade } \\
\text { regional. (Valor: } \mathrm{R} \$ 121.606,35 \text { ) }\end{array}$ & $\begin{array}{lr}\text { Funcionários } & \text { do } \\
\text { porto, OGMO, } \\
\text { funcionários das } \\
\text { empresas } \\
\text { usuárias, } \\
\text { comunidade } \\
\text { entorno do } \\
\text { usuários } & \text { e } \\
\text { embarcações } & \\
\text { fluviais. } & \end{array}$ & $\begin{array}{l}02 / 12 / \\
2011\end{array}$ & $\begin{array}{l}02 / 12 / 20 \\
12\end{array}$ \\
\hline $\begin{array}{lr}\text { Projeto } & \text { de } \\
\text { Educação } & \\
\text { Ambiental } & \text { para } \\
\text { Todos- } & \text { PEAT } \\
2012 / 2013 & \end{array}$ & $\begin{array}{l}\text { Sensibilizar a comunidade portuária a } \\
\text { contribuir com a correta coleta, seleção e } \\
\text { disponibilização dos resíduos gerados, } \\
\text { promovendo a melhoria da qualidade de vida } \\
\text { da população por meio da conservação do } \\
\text { meio ambiente. (R } \$ 119.820,00)\end{array}$ & $\begin{array}{lr}\text { Associação das } \\
\text { mulheres do } \\
\text { Bairro do } \\
\text { Aeroporto Velho } \\
\text { e Mapiri, } \\
\text { tripulação } \\
\text { usuários das } \\
\text { embarcações } \\
\text { fluviais, } \\
\text { empregados } \\
\text { terceirizados da } \\
\text { CDP, } \\
\text { carregadores de } \\
\text { bagagem, taxistas, } \\
\text { mototaxistas, } \\
\text { vendedores de } \\
\text { lanche, } \\
\text { vendedores } \\
\text { passagem, de } \\
\text { trabalhadores do } \\
\text { OGMO e artesãs. }\end{array}$ & $\begin{array}{l}20 / 11 / \\
2012\end{array}$ & $\begin{array}{l}20 / 11 / 20 \\
13\end{array}$ \\
\hline $\begin{array}{l}\text { Projeto Saberes e } \\
\text { práticas de } \\
\text { responsabilidade } \\
\text { social na Rui } \\
\text { Paranatinga } \\
\text { Barata: ações } \\
\text { socioeducativas } \\
\text { no entorno do } \\
\text { Terminal } \\
\text { Petroquímico de } \\
\text { Miramar. }\end{array}$ & $\begin{array}{l}\text { Desenvolver ações de responsabilidade } \\
\text { socioambiental junto aos docentes e discentes } \\
\text { da escola Rui Paranatinga Barata, de modo a } \\
\text { envolver a todos na construção de novas } \\
\text { intervenções socioambientais, considerado as } \\
\text { especificidades da comunidade e suas } \\
\text { contradições. (Valor: R\$ } 150.000,00)\end{array}$ & $\begin{array}{l}\text { Docentes } \\
\text { discentes da } \\
\text { escola } \\
\text { Paranatinga } \\
\text { Barata, pais e } \\
\text { demais membros } \\
\text { da comunidade } \\
\text { escolar. }\end{array}$ & $\begin{array}{l}02 / 09 / \\
2013\end{array}$ & $\begin{array}{l}02 / 09 / 20 \\
14\end{array}$ \\
\hline
\end{tabular}


Quadro 3: Continuação...

\begin{tabular}{|c|c|c|c|c|}
\hline \multirow[t]{2}{*}{ Projeto } & \multirow[t]{2}{*}{ Objetivo } & \multirow[t]{2}{*}{ Público alvo } & \multicolumn{2}{|c|}{ Prazo } \\
\hline & & & Inicio & Término \\
\hline $\begin{array}{l}\text { Projeto Saberes e } \\
\text { práticas de } \\
\text { responsabilidade } \\
\text { social na Escola } \\
\text { Wandick } \\
\text { Gutierrez: ações } \\
\text { socioeducativas } \\
\text { no entorno do } \\
\text { Porto de Vila do } \\
\text { Conde. }\end{array}$ & $\begin{array}{l}\text { Desenvolver ações de responsabilidade } \\
\text { socioambiental por meio de pesquisa, extensão } \\
\text { no interior da Escola Wandick Gutierrez e na } \\
\text { comunidade da Vila do Conde de modo a } \\
\text { envolver toda a comunidade escolar na } \\
\text { construção de novas intervenções } \\
\text { socioambientais, considerado a a } \\
\text { especificidades da comunidade e suas } \\
\text { contradições. (Valor: R\$150.000,00) }\end{array}$ & $\begin{array}{l}\text { Docentes } \\
\text { discentes da } \\
\text { escola Wandick } \\
\text { Gutierrez, pais e } \\
\text { demais membros } \\
\text { da comunidade } \\
\text { escolar. }\end{array}$ & \begin{tabular}{|l|}
$09 / 06 /$ \\
2011
\end{tabular} & \begin{tabular}{|l|}
$08 / 06 / 20$ \\
12
\end{tabular} \\
\hline $\begin{array}{l}\text { Projeto Saberes e } \\
\text { práticas de } \\
\text { responsabilidade } \\
\text { socioambiental na } \\
\text { Escola Augusto } \\
\text { Montenegro: } \\
\text { ações } \\
\text { socioeducativas } \\
\text { nos bairros do } \\
\text { entorno do Porto } \\
\text { de Belém. }\end{array}$ & $\begin{array}{l}\text { Trabalhar a responsabilidade socioambiental } \\
\text { da CDP/Porto de Belém junto à comunidade } \\
\text { do entorno do Porto, no sentido de garantir o } \\
\text { retorno e compromisso social da empresa para } \\
\text { com a comunidade, baseando-se em uma } \\
\text { política de intervenção socioambiental, a partir } \\
\text { de práticas embasadas na Educação } \\
\text { Ambiental, direcionada para o entendimento } \\
\text { coerente e problematizado dos problemas } \\
\text { ambientais e possibilidade de intervenção } \\
\text { qualificada na comunidade envolvida. (Valor: } \\
\mathrm{R} \$ 150.000,00)\end{array}$ & \begin{tabular}{|lr} 
Docentes & $\mathrm{e}$ \\
discentes & da \\
escola Augusto & Aurais \\
Montenegro, pais \\
e r demais \\
membros r da \\
comunidade r \\
escolar; rr r
\end{tabular} & $\begin{array}{l}02 / 03 / \\
2012\end{array}$ & $\begin{array}{l}01 / 03 / 20 \\
13\end{array}$ \\
\hline $\begin{array}{lr}\text { Projeto } & \text { de } \\
\text { Educação } & \\
\text { Ambiental } & \text { para } \\
\text { Todos- } & \text { PEAT } \\
2014 & \end{array}$ & 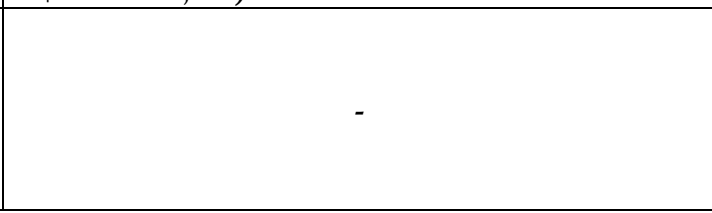 & $\begin{array}{c}\text { - } \\
\text { (Valor: R\$ } \\
120.540,00)\end{array}$ & $\begin{array}{l}11 / 04 / \\
2014\end{array}$ & $\begin{array}{l}11 / 04 / 20 \\
15\end{array}$ \\
\hline
\end{tabular}

Fonte: Elaborado a partir de CDP (2014a; 2014b)

com cuidado. Houve derrame, porque antigamente isso aqui, derramava a gente não queria saber, era pago e acabou. Hoje em dia não. Hoje temos mais aquele cuidado, entendeu, com o próprio companheiro, mais com próprio produto que estamos trabalhando. Derramava, derramou, derramou! Deixa, falava, acabou. Hoje temos cuidado para que não aconteça mais isso. [Trabalhador Portuário 1].

Aumentou a consciência. [...] Antigamente o pessoal terminavam jogava [no rio]. Até resíduo de combustível, antigamente, de combustível era jogado no rio.[...] [Trabalhador Plantonista]

Cabe fazer duas pontuações, a partir das entrevistas acima (com os trabalhadores). Primeiro, esse engajamento dos trabalhadores não significa passividade nesse processo, principalmente porque esses agentes estão imersos no Campo Portuário, e, segundo Bourdieu (1997), qualquer campo é um "campo de lutas dentro dos quais agentes se enfrentam, com meios ou fins diferenciados segundo sua posição na estrutura do campo de forças" (BOURDIEU, 1997, p.49).

Um dos fatos que ilustra essas lutas de forças é a resistência dos trabalhadores no Terminal Petroquímico de Miramar às práticas de Educação Ambiental, ao ponto de boicotarem algumas dessas práticas socioambientais:

Eles fizeram tipo umas aulas..., de teatro, aí [trabalhadores] começaram que aquilo era..., é o preconceito, ficou como tipo do preconceito [...] [Entrevista com Trabalhador de Serviços Gerais]. A nossa área é essa como está vendo, nós não temos uma sala adequada para gente fazer para ficar mais a vontade, né. Se a gente tivesse, tenho certeza, que não só eu como os outros. Aquele que tiver interessado vão participar mesmo de verdade. Mas no nosso caso, como acabei de 
dizer começa e acaba desmotivada, chega aí, vai se deitar, onde bicho, cachorro passa por aqui [Entrevista com Trabalhador portuário].

Outra resistência é que muitos trabalhadores mesmo já "realizado" cursos de coleta seletiva, não depositavam os resíduos nos recipientes corretos:

Já tiveram momentos de fazer, separar papel de papel, plástico com plástico, orgânico com orgânico e assim por diante, e, eu acho, nesse ponto está devendo. Têm poucas pessoas que têm consciência [Entrevista com Trabalhador de Serviços Gerais].

O segundo aspecto (pontuação), sobre as entrevistas dos trabalhadores portuários, relaciona-se ao o estímulo ao engajamento ambiental portuário dos trabalhadores. Segundo Rodrigues (2012), seria uma maneira de evitar perda de capital simbólico (reconhecimento, respeito, da boa imagem da empresa ecológica) da companhia/empresa e de seus parceiros, em caso de um possível acidente ambiental de grandes proporções (RODRIGUES, 2012). A partir dessa reflexão, o marketing é um ferramenta da divulgação da boa imagem da empresa, para legitimar a empresa como a precursora da proteção ambiental e incapaz degradar o meio ambiente, e, portanto não tenha sua imagem denegrida e sofra multas, em caso de acidentes (GUILHERME et al., 2013). Isso é evidenciado ou confirmado pela Agência Nacional de Transportes Aquaviários - ANTAQ (2011) (agência que é responsável por organizar/mediar às regras e as normas do jogo do campo portuário):

É importante que a matéria ambiental alcance o nível de decisão da organização, sendo incorporada às questões estratégicas da atividade, tornando-se assunto relevante e criando uma imagem de boas práticas ambientais da instituição. Trata-se, por exemplo, de dar respostas imediatas às demandas nesse campo, como nos casos de acidentes com cargas poluentes. Os acidentes ambientais, quaisquer que sejam suas proporções, denigrem a imagem da instituição, atingindo seus aspectos comerciais (ANTAQ, 2011a, [s.p.]).

Segundo Rodrigues (2012) a matéria ambiental é fundamental, para não fragilizar, no caso de acidentes, a relação com os parceiros desse campo (que no caso da CDP, as empresas-parceiras principais são: Albrás, Alunorte, Cargill, Bunge e Vale); a atração de novos parceiros para arrendamento da área portuária; e a valorização das ações na bolsa de valores de todos os componentes do campo portuário (ANTAQ, 2011a).

Portanto, a dimensão ambiental torna-se fonte de preocupações (de apropriação, incorporação, "transformação" e promoção), com a aplicação de códigos de conduta (ou orientações), pois impulsiona o projeto de expansão da "matriz racional" do capital, a partir "Il s'agit de faire paraître l'entreprise comme un acteur responsable de ses actes, capable de bien agir en vue de 'protéger la nature' [...]" (LEFÈVRE, 2008, p.157).

\section{CONSIDERAÇÕES FINAIS}

Ao longo deste artigo, buscou-se construir, sistematicamente, aproximações sobre o fenômeno que vem sendo chamado de "ambientalização empresarial portuária", no qual se identificou o Port marketing and the challenge of the third generation port/UNCTAD, como a "ideia reguladora", cujo pressuposto é pautado em modelos conceituais de portos: segue o discurso-guia de reaproximação e integração porto-cidade, medidas de proteção ambiental e respeito ao meio ambiente e a seguridade.

Observou-se, nas ações já realizadas em outros portos (por meio do Plano Nacional de Capacitação Ambiental Portuário (PNCAP) e nos Portos da CDP (confirmados no estudo de caso dessa pesquisa), que as características das ações socioambientais que reproduzem a "ideia reguladora" da UNCTAD supracitada centram-se em capacitações para o desenvolvimento de atitudes pró-ativas e nos trabalhadores portuários; e, no uso da Educação Ambiental.

Além disso, a análise crítica mostrou que a inserção da dimensão ambiental (a inserção dessa lógica) tornou-se fonte de "preocupações" e ações do setor portuário, como uma oportunidade/utilitarismo, fonte de vantagem competitiva e saúde empresarial: (1) para publicização de uma boa imagem 
da empresa; (2) diminuir investimentos em tecnologias e planejamentos; (3) conseguir a legitimação do modus operandi portuário, já que é insustentável e com altos riscos ambientais; (4) qualificação maciça e contínua dos trabalhadores para que façam o gerenciamento ambiental dos negócios da empresa. Em síntese, o contrabando do "ambiental" pela área empresarial portuária representa um novo mecanismo para sustentar a lógica interminável e insaciável de acumulação de capital, sobretudo no Brasil, e particularmente na Amazônia.

Essa "preocupação" é fundamental, pois os aspectos comerciais à matéria ambiental são imprescindíveis, pois a sua ausência fragilizaria: a) a relação com os parceiros; b) a atração de novos parceiros; c) a valorização das ações na bolsa de valores de todos os componentes. A relação porto-cidade, nesse contexto, é fundamental, pois tenta passar a ideia que as riquezas que "circulam pelos portos" são repassadas à sociedade, assim possibilitar o aumento das territorialidades de poder, isto é, as fontes legitimadoras. Aliás, estratégia essa (aumento das territorialidades de poder), vem se reproduzindo nos projetos de Educação Ambiental e responsabilidade socioambiental dos portos da CDP.

Portanto, a importância desta pesquisa (e para pesquisas posteriores) encontra-se assentada em dois pontos. A primeira, incentivar pesquisas ambientais (portuária) sob perspectiva crítica, cuja ênfase é desvelar os interesses (e ações) dessas "preocupações" do setor empresarial portuário, principalmente com o processo de ambientalização. Mostra-se, assim, que há uma "ideia reguladora" perversa do grande capital, que, segundo Rodrigues, Castro e Figueiredo (2013a, p.276), chama-se gestão ambiental portuária:

[...] [é uma] ferramenta moderna de dominação/legitimação e técnica de manipulação gerenciada para adequar a estrutura organizacional às necessidades da mundialização de trocas materiais e imateriais, possibilitando a constituição de uma postura proativa de gestão ambiental, em conformidade às lógicas de mercado e do campo portuário.

A segunda relevância dessa pesquisa e para pesquisas posteriores, encontra-se, principalmente, diante do cenário atual de atuações do Estado e do grande capital, por meio de grandes empreendimentos econômicos e investimentos em logística portuária (CASTRO, 2012) e, consequentemente, na inserção e no fortalecimento da dimensão ambiental na área portuária, assim como por ações, dentro e no entorno dos portos (nas interações, relação porto-cidade).

\section{REFERÊNCIAS}

ACSELRAD, H. Ambientalização das lutas sociais: o caso do movimento de justiça ambiental. Estudos Avançados, v.24, p.103-120, 2010.

ACSELRAD, H. A Desigualdade Ambiental na conjuntura atual: uma análise sobre a Rio +20 e seus possíveis desdobramentos (Entrevista com o Professor Henri Acselrad). Revista IDeAS, v.6, n.2, p.216-226, 2012.

ALVES, G. Dimensões da Reestruturação Produtiva - Ensaios de sociologia do trabalho. $2^{\mathrm{a}}$ ed. Londrina: Praxis; Bauru: Canal 6, 2007.

Dimensões da reestruturação produtiva do capital: notas teórico-metodológicas. O Público e o

Privado, v.11, p.9-20, 2008.

[ANTAQ] AGÊNCIA NACIONAL DE TRANSPORTES AQUAVIÁRIOS. O porto verde: modelo ambiental portuário. Brasília: ANTAQ, 2011a.

Agendas ambientais portuárias. Brasília: ANTAQ, $2011 \mathrm{~b}$.

Panorama Aquaviário. V.6, ago 2011. Disponível em: <http://www.antaq.gov.br/Portal/pdf/

PanoramaAquaviario6.pdf>. Acesso em: 07 jan. 2012a.

Anexo da resolução 2969 - antaq de 4 de julho de 2013, que define a classificação dos portos públi- 
cos, terminais de uso privado e estações de transbordo de cargas em marítimos, fluviais e lacustres. Disponível em: <http://www.antaq.gov.br/Portal/pdf/Classificacao_PortosPublicos_TUPs_EstacoesTransbordoCargas. pdf $>$. Acesso em: 06 maio 2014a.

PNCAP - Programa Nacional de Capacitação Ambiental Portuária. Disponível em: <http://www. antaq.gov.br/portal/MeioAmbiente_PNCAP_Estrutura.asp>. Acesso em: 24 jun.2014b.

. Meio ambiente - Gestão Ambiental. Disponível em: <http://www.antaq.gov.br/portal/MeioAmbiente_GestaoAmbiental.asp>. Acesso em: 25 jun.2014c.

ASSIS, L. F. S. de. Interdisciplinaridade: necessidade das ciências modernas e imperativo das questões ambientais. In: PHILIPPI JR., A.; TUCCI, C. E. M.; HOGAN. D. J.; NAVEGANTES, R. Interdisciplinaridade em Ciências Ambientais. São Paulo: Signus Editora, 2000. p.171-184.

ASSUNÇÃO, C. M. L.; VIEIRA, J. P. Projeto de educação ambiental para o porto organizado de São Sebastião (PEA/PORTO-SS). São Sebastião, Marinha do Brasil, Diretoria de Portos e Costas, 2005. Disponível em: $<$ https://www.dpc.mar.mil.br/epm/portuarios/Ed_Ambiental/indice.htm>. Acesso em: 24 ago. 2011.

BANCO MUNDIAL. Port Reform Toolkit. $2^{\mathrm{a}}$ ed. Washington: Banco Mundial, 2007. 362p. Disponível em: $<$ http://ppp.worldbank.org/public-private-partnership/library/port-reform-toolkit-ppiaf-world-bank-2nd-edition>. Acesso em: 12 Fev. 2014

BERGQVIST, R.; EGELS-ZANDÉN, N. Green port dues - The case of hinterland transport. Research in Transportation Business \& Management, v.5, p.85-91. 2012.

BOURDIEU, P. O poder simbólico. São Paulo: Bertrand Brasil/DIFEL, 1989.

Razones práticas - sobre la teoria de la acción. Barcelona: Anagrama, 1997.

Meditações pascalianas. Rio de Janeiro: Bertrand Brasil, 2001.

BOURDIEU, P.; WACQUANT, L. O imperialismo da razão neoliberal. Revista Sociologia em Rede, v.3, n.3, p.82-87, 2013.

BRASIL. Ministério do Planejamento, Orçamento e Gestão. Secretaria de Planejamento e Investimentos Estratégicos. Estudo da Dimensão Territorial para o Planejamento: Volume IV. Brasília: MP, 2008b. 288 p.

CAMPO, J. G. Curso de educação ambiental - uma introdução à gestão ambiental portuário. Santos, Marinha do Brasil, Diretoria de Portos e Costas, 2004. Disponível em:<http://www.dpc.mar.mil.br/epm/portuarios/ Ed_Ambiental/Salvador_Conceicao.pdf $>$. Acesso em: 26 ago. 2011.

CASTRO, E. M. R.2012CASTRO, E. M. R. Expansão da Fronteira, megaprojetos de infraestrutura e integração sul-americana. Caderno CRH, v.25, p.45-62, 2012.

CASTRO, S. M.; ALMEIDA, J. R. Dragagem e conflitos ambientais em portos clássicos e modernos: uma revisão. Sociedade e Natureza, v.24, n.3, p.519-533, 2012.

[CDP] COMPANHIA DOCAS DO PARÁ. Relatório de Gestão do Exercício de 2000. Belém, 2001. Disponível em: <https://www.cdp.com.br/relatorios-de-gestao/relatorios-anuais>. Acesso em: 15 Jan. 2014.

Relatório de Gestão do Exercício de 2003. Belém, 2004. Disponível em: <https://www.cdp.com.br/ relatorios-de-gestao/relatorios-anuais>. Acesso em: 18 Jan. 2014.

Relatório de Gestão do Exercício de 2009. Belém, 2010a. Disponível em: <https://www.cdp.com.br/ relatorios-de-gestao/relatorios-anuais>. Acesso em: 19 Jan. 2014. 
Projeto de Educação Ambiental no Porto de Belém. Belém: CDP, 2010b. (impresso).

Convênios. Disponível em: <http://www.cdp.com.br/convenios>. Acesso em: 25 Jun. 2014a.

Projetos de Educação ambiental e Responsabilidade Socioambiental. Disponível em: <http://www. cdp.com.br/projetos-de-educacao-ambiental-e-responsabilidade-socioambiental>. Acesso em: 25 Jun. $2014 \mathrm{~b}$.

COMISION EUROPEA. Libro verde sobre los puertos y las infraestructuras marítimas. Bruxelas: CE, 1997. Disponível em: <http://cde.uv.es/documents/1997-COM-678.pdf>. Acesso em: 21 jul. 2011.

COSTA, C. S. C. Gestão ambiental portuária: um estudo sobre as experiências desenvolvidas no porto de Belém. 90f. Monografia (Graduação em Pedagogia), Universidade Federal do Pará, Belém, 2013.

CUNHA, I. A. Agenda Ambiental Portuária: a Competitividade dos Portos e a Negociação de Conflitos. Gerenciamento Costeiro Integrado, v.5, p.34-39, 2006.

CUNHA, I. A. Negociação ambiental em áreas portuárias e sustentabilidade. São Paulo em Perspectiva, v.20, p.59-70, 2007.

CUNHA, I. A.; VIEIRA, J. P.; REGO, E. H. Sustentabilidade da atividade portuária rumo à agenda ambiental para o porto do canal de São Sebastião. eGesta, v.3, n.1, p.7-32, 2007.

DEBRIE, J.; LETILLEUL, V. L.; PAROLA, F. Shaping port governance: the territorial trajectories of reform. Journal of Transport Geography, n.27, p.56-65, 2013.

DAVIS, J. D., et al. Environmental considerations for port and harbour developments. Washington: World Bank, 1990. Disponível em: <http://www.rhd.gov.bd/Documents/ ExternalPublications/WorldBank/TransSectPub/contents/documents/B37.pdf>. Acesso em: 21 jul.2011.

FREITAS, D. R. T. Reestruturação produtiva e portuária no Brasil: análise dos portos de Suape, PE; Itaguaí, RJ; Açu, RJ. 73f. Dissertação (Mestrado Planejamento Regional e Gestão de Cidades) - Programa de Pós-Graduação em Planejamento Regional e Gestão de Cidades, Universidade Candido Mendes, Campos dos Goytacazes, 2011.

GARCIA, M. L. Z. A auto-atividade na educação ambiental, uma ferramenta para a ação "no fazer" humano: O ambiente transformador do trabalho portuário avulso do Rio Grande. 165f. Dissertação (Mestrado em Educação Ambiental) - Programa de Pós-Graduação em Educação Ambiental, Fundação Universidade Federal do Rio Grande, Rio Grande, 2005.

GARCIA, D. S. S. A atividade portuária como garantidora do princípio da sustentabilidade. Revista de Direito Econômico e Socioambiental, v. 3, n.2, p.375-399, 2012.

GONZÁLEZ-LAXE, F. Transporte marítimo y reformas portuarias: los modelos europeos y latinoamericanos. Boletín Económico de ICE, n.2931, p.43-64. 2008.

26. 2010. Las ciudades portuarias después de la crisis. Boletín Económico de ICE, n.3002, p.15-

2011. La accesibilidad y conectividad portuaria. Boletín Económico de ICE, n.3011, p.35-46.

GOULIELMOS, A. M. European policy on port environmental protection. Global Nest, v.2, n.2, p.189-197, 2000.

GUILHERME, J. T. et al. Gestão e diagnóstico ambiental: um estudo de caso em um porto de Santa Catarina, 
Brasil. Revista da Gestão Costeira Integrada, v.13, p.353-363, 2013.

JUHEL, M. H. Globalisation, Privatisation and Restructuring of Ports. International Journal of Maritime Economics, v.3, p.139-174, 2001.

KAISER, I. M.; BEZERRA, B. S.; CASTRO, L. I. S. Is the environmental policies procedures a barrier to development of inland navigation and port management? A case of study in Brazil. Transportation Research Part A: Policy and Practice, v.47, p.78-86. 2013.

KITZMANN, D. I. S. Ambientalização sistêmica na gestão e na educação ambiental: estudo de caso com o Ensino Profissional Marítimo - EPM. 239f. Tese (Doutorado em Educação Ambiental) - Programa de Pós-Graduação em Educação Ambiental, Universidade Federal de Rio Grande, Rio Grande, 2009.

KITZMANN, D. I. S.; ASMUS, M. Avaliação da percepção ambiental: estudo de caso com trabalhadores portuários. Revista Eletrônica do Mestrado em Educação Ambiental, v.5-6, p.69-80. 2001.

Gestão ambiental portuária: desafios e possibilidades. Revista de Administração Pública, v.40, n.6, p.965-1192, 2006.

KOEHLER, P. H. W.; ASMUS, M. L. Gestão ambiental integrada em Portos Organizados: uma análise baseada no caso do porto de Rio Grande, RS - Brasil. Revista da Gestão Costeira Integrada, v.10, n.2, p.201-215, 2010.

LEFF, E. Complexidade, interdisciplinaridade e saber ambiental. In: PHILIPPI JR, A.; TUCCI, C. E. M.; HOGAN D. J.; NAVEGANTES, R. Interdisciplinaridade em Ciências Ambientais. São Paulo: Signus Editora, 2000. p.19-51.

LEFÈVRE, M. «L' « écologisme d'entreprise»: inscrire la considération écologique au cœur de la firme ?». Ecologie \& politique, v.3, n.37, p.153-163, 2008.

LIMA, M. P. O desenvolvimento sustentável da cidade portuária na perspectiva do processo de globalização: Cabedelo-PB e o seu porto. 141f. Dissertação (Mestrado em Engenharia Urbana e Ambiental) - Programa de Pós-Graduação em Engenharia Urbana e Ambiental, Universidade Federal a Paraíba, João Pessoa, 2009.

LOURENÇO, A. V. Diretrizes para um Plano de Gestão Ambiental Portuário Contextualizado nos estágios do Ciclo do GCI. Estudo de caso no Porto do Rio Grande. 181f. Dissertação (Mestrado em Gestão Costeira) Programa de Pós Graduação em Gerenciamento Costeiro, Universidade Federal do Rio Grande, Rio Grande, 2012.

LOWY, M. Crise ecológica, crise capitalista, crise de civilização: a alternativa ecossocialista. Caderno CRH, v.26, n.67, p.79-86, 2013.

MONIÉ, F.; VIDAL, S. M. S. Cidades, portos e cidades portuárias na era da integração produtiva. Revista de Administração Pública, v. 40, n.6, p.975-995, 2006.

MUNHOZ, D. G. Obstáculos ambientais e não ambientais ao desenvolvimento. In: CARDOSO JR, J. C. (Org.). Desafios ao desenvolvimento brasileiro: contribuições do conselho de orientação do IPEA. Brasília: IPEA, 2009. v.1. p.115-151.

NUNES, A. R. da S. Educação Ambiental Crítica e Sustentabilidade em Portos na Amazônia: o Programa de educação Ambiental da Companhia Docas do Pará. 145f. Dissertação (Mestrado em Educação) - Programa de Pós-Graduação em Educação, Universidade Federal do Pará, Belém, 2012.

NUNES, A. R. da S.; SILVA, M. L. da; ARAÚJO, M. L. Educação ambiental portuária: trajetórias educativas da companhia docas do Pará (terminal petroquímico de Miramar) em Belém/ PA. Revista Eletrônica Mes- 
trado em Educação Ambiental, v.especial, p.80-92, 2013.

QUINTANA, J. L. Projeto de educação ambiental: trabalhadores portuários avulsos em Salvador-BA. Salvador, Marinha do Brasil, Diretoria de Portos e Costas, 2005. Disponível em:<http://www.dpc.mar.mil.br/epm/ portuarios/Ed_Ambiental/indice.htm>. Acesso em: 24 ago. 2011.

REIS, R. C. dos. Políticas e tensões entre o porto e o espaço escolar em Vila do Conde - Barcarena/PA. 169f. Dissertação (Mestrado em Educação) - Programa de Pós-Graduação em educação, Universidade Federal do Pará, Belém, 2013.

RICHARDSON, R. J. Pesquisa social: métodos e técnicas. $3^{\text {a }}$ ed. São Paulo: Atlas, 2008.

RIOS, R. B. Porto de Aratu no contexto industrial baiano: indicadores de desempenho e os operadores portuários. Sociedade \& Natureza, v.21, n.3, p.341-350, 2009.

RODRIGUES, J. C. Educação Ambiental e Estratégias Empresariais na Área Portuária: um estudo da Companhia Docas do Pará (CDP). 219f. Dissertação (Mestrado em Ciências Ambientais) - Programa de Pós-Graduação em Ciências Ambientais, Universidade Federal do Pará, Belém, 2012.

RODRIGUES, J. C.; CASTRO, E. M. R. Companhia Docas do Pará (CDP): plataforma logística do capital internacional na Amazônia Oriental. Contribuciones a las Ciencias Sociales, v. 20, p. 1-14, 2013.

RODRIGUES, J. C.; CASTRO, E. M. R.; FIGUEIREDO, S. J. L. Política Ambiental Portuária Brasileira: gênese, agenda pública e interesses subjacentes. DELOS: Desarrollo local sostenible, v.6, p.1-22, 2013a.

RODRIGUES, J. C.; CASTRO, E. M. R.; FIGUEIREDO, S. J. L. Educação Ambiental e Estratégias Empresariais na Área Portuária: um Estudo da Companhia Docas do Pará (CDP). Revista Eletrônica do Mestrado em Educação Ambiental, v.30, p.264-280, 2013b.

RODRIGUES, R. C. A.; LEMOS, L. M. New territorial dynamics in the brazilian port system: logistics networks and local development in açu and barra do furado port complexes. L'Espace Politique, v.16, n.1, 2012.

ROLDÃO, L. B. Proposta de indicadores de avaliação em Educação Ambiental: uma reflexão sobre o Programa de Educação Ambiental Portuária a partir da linha de ação Educação Ambiental Portuária no Contexto do Ensino Formal. 128f. Dissertação (Mestrado em Educação Ambiental) - Programa de Pós-Graduação em Educação Ambiental, Universidade Federal do Rio Grande, Rio Grande, 2009.

SÁ, M. E. M. Análise comparativa entre os portos de Recife e Suape: desafios para a gestão ambiental. 110f. Dissertação (Mestrado em Desenvolvimento e Meio Ambiente) - Programa de Pós-Graduação em Desenvolvimento e Meio Ambiente, Universidade Federal de Pernambuco, Recife, 2008.

SAENGSUPAVANICH, C. et al. Environmental performance evaluation of an industrial port and estate: ISO14001, port state control-derived indicators. Journal of Cleaner Production, v.17, n.2, p.154-161. 2009.

SANTOS, R. de S. Problemas ambientais e relações de trabalho no porto de Belém: perspectivas para um projeto de Educação Ambiental. 125f. Dissertação (Mestrado em Gestão de Recursos Naturais e Desenvolvimento Local) - Programa de Pós-Graduação Gestão de Recursos Naturais e Desenvolvimento Local, Universidade Federal do Pará, Belém, 2013.

SILVA, D. N. Gestão ambiental na Companhia Docas do Pará - Terminal Petroquímico de Miramar. 68f. Monografia (Especialização em Gestão Ambiental) - Programa de Formação Interdisciplinar em Meio Ambiente, Núcleo de Meio Ambiente, Universidade Federal do Pará, Belém, 2006.

SILVA, M. L. Projeto de educação ambiental: Terminal Petroquímico de Miramar. Boletim Informativo, GEAM, Ano 1, n.1, p.1-4, Belém. 2008. (impresso) 
SOARES, C. R. Os Portos de Paranaguá (PR) e Itajaí (SC): análise comparativa das suas relações com as cidades de inserção, da estrutura operacional atual e das condições sócio-ambientais das regiões de entorno. 204f. Tese (Doutorado em Meio Ambiente e Desenvolvimento)- Pós-Graduação em Meio Ambiente e Desenvolvimento, Universidade Federal do Paraná, Curitiba, 2009.

TEISSERENC, P. Ambientalização e territorialização: situando o debate no contexto da Amazônia Brasileira. Antropolítica (UFF), v. 2, p. 153-179, 2011.

[UNCTAD] CONFERÊNCIA DAS NAÇÕES UNIDAS SOBRE COMÉRCIO E DESENVOLVIMENTO. Port development: the role of UNCTAD. Geneve: UNCTAD, 1990. Disponível em: <http://r0.unctad.org/ttl/ docs-un/td-b-c4-ac7-7/en/TDBC4AC77e.pdf>. Acesso em: 12 Jan. 2014.

Port marketing and the challenge of the third generation port. Geneve: UNCTAD, 1992. Disponível em: <http://r0.unctad.org/ttl/docs-un/td-b-c4-ac7-14/en/TD\%20B\%20C4\%20AC7\%2014e.pdf>. Acesso em: 15 Jan. 2014.

Sustainable development for ports. Geneve: UNCTAD, 1993. Disponível em: <http:// r0.unctad.org/ttl/docs-un/unctad-sdd-port-1/en/g9353203.pdf>. Acesso em: 17 Jan. 2014.

. Sustainable development strategies for cities and ports. Geneve/New York: UNCTAD, 1996. Disponível em: <http://unctad.org/en/docs/ship49414_en.pdf>. Acesso em: 17 Jan. 2014.

VASCONCELOS, F. N. O desenvolvimento da interface cidade-porto em Vitória (ES) do período colonial ao início do século XXI: uma cidade portuária?. 463f. Tese (Doutorado em Ciências Sociais) - Programa de Pós-Graduação em Ciências Sociais, Pontifícia Universidade Católica de São Paulo, São Paulo, 2011.

WOOLDRIDGE, C. F., MCMULLEN, C.; HOWE, V. Environmental management of ports and harbours implementation of policy through scientific monitoring. Marine Policy, v.23, n.4-5, p.413- 425, 1999.

YIN, R. K. Estudo de caso: planejamento e métodos. $3^{\text {a }}$ ed. São Paulo: Boockman, 2005.

ZACARIAS, R. A lógica destrutiva do processo de acumulação do capital e a destruição ambiental. Praia Vermelha (UFRJ), v.19, p.65-72, 2009. 